\title{
Intersecciones en las configuraciones de la maternidad en la historia argentina, 1900-1946: registros médicos y culturales bajo la lupa
}

\author{
Intersections in the configurations of motherhood in the history of \\ Argentina, 1900-1946: medical and cultural records under the microscope
}

\section{Karina Felitti}

Investigadora, Conicet, Instituto Interdisciplinario de Estudios de Géneros/Universidad de Buenos Aires.

karinafelitti@gmail.com

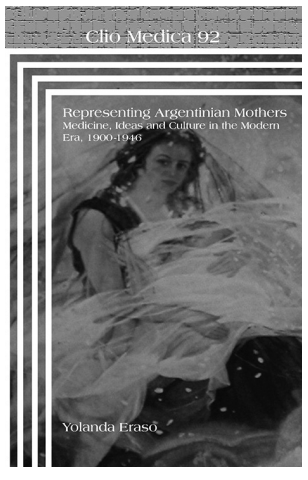

ERASO, Yolanda. Representing Argentinian mothers: medicine, ideas and culture in the Modern Era, 1900-1946. Amsterdam: Rodopi. 2013. 293p.

\section{$\mathrm{E}$} n un momento en que los derechos del parto y las denuncias de la violencia obstétrica se posicionan fuertemente en la agenda del movimiento de mujeres y de algunos feminismos, este libro viene a hablarnos de las representaciones de la maternidad y sus circulaciones en la Argentina del siglo pasado, cuando algunas de estas formas de control social sobre el cuerpo de las mujeres se impusieron y se resistieron. La medicalización del parto y la extensión del poder médico toman una forma específica, material, situada, que se sale de los espacios usuales de enunciación, incluso por el hecho de usar una provincia como centro de análisis y extender al resto del país lo que se sabe de Buenos Aires. En ese sentido, Erazo reconoce el trabajo pionero de Marcela Nari (2004) sobre la politización de la maternidad y la maternalización de las mujeres y sus aportes para entender las relaciones tejidas entre las políticas públicas y las preocupaciones demográficas y médicas, pero aclara que su estudio no está centrado en las políticas de maternidad, ni en las leyes y ni en los debates que rodearon su sanción.

A partir de un abordaje interdisciplinario, Eraso propone analizar los principales determinantes (médicos, sociales, culturales, religiosos) de las representaciones de la maternidad en la Argentina de la primera mitad del siglo XX. Esta combinación de perspectivas es uno de los principales aportes del libro, el hacer dialogar registros de diversas procedencias y estudiar sus circulaciones. Así, cuando analiza la medicalización de la maternidad y los alcances del discurso médico, atiende a diferentes esferas significantes, como son las publicaciones periódicas, la literatura y el arte. Así estudia dos dimensiones, los conceptos y las prácticas médicas, retoma algunas preguntas que parecían ya contestadas por otros estudios y logra encontrar nuevas respuestas. Por ejemplo, cuando se ubica en la discusión sobre la existencia 
en la Argentina de una eugenesia "negativa" o de una "positiva". De acuerdo a Nancy Stepan, este país siguió la tendencia de América Latina de "prevenir" y no tanto de "proscribir" riesgos hereditarios en la reproducción. Sin embargo, la autora pone en duda que no existieran medidas restrictivas puesto que en los consultorios pre nupciales y de pre concepción se desaconsejaba la reproducción en determinadas circunstancias. Si bien no son muchos casos, su existencia resultaría suficiente para considerar necesario revisar lo que hasta ahora se ha sostenido en relación a este tema.

Otra cuestión importante que muestra la obra es lo fundamental de distinguir entre lo que sucedía en la capital federal y lo que pasaba en el resto del país. Por ejemplo, cuando se habla del parto institucionalizado en la Argentina hay que considerar que para 1938 tan solo en Buenos Aires había 19 centros de maternidad y en el resto del país 23, localizados en las capitales provinciales y solo parcialmente equipados. Con estos números no se debería hablar de hospitalización de partos en todo el país puesto que no había instituciones donde hacerlo, especialmente en el norte e incluso en ciudades importantes como Córdoba y Santa Fe. Para darle mayor contenido a esta diferenciación, Eraso toma como caso de estudio la provincia de Córdoba, cuya capital es la segunda ciudad de la Argentina, con una cercanía mayor a la tradición católica y una elite que, a diferencia de la porteña, no basaba su poderío en la propiedad de la tierra sino en profesiones liberales y el prestigio de su universidad.

El libro se organiza en tres partes. La primera, "El registro médico", describe la preocupación médica por educar el "instinto maternal" y presenta los debates entre los intervencionistas y los que esperan el desencadenamiento del parto, es decir, entre los que prefieren las cesáreas, utilizar drogas para acelerar las contracciones o romper la bolsa de aguas, y los que rechazan las cirugías. Un punto interesante de este análisis es la importancia asignada a la base material en la que se asientan los cambios. Por ejemplo, cuando se afirma que se procura correr a las parteras de su lugar protagónico en los nacimientos, Eraso señala como condición necesaria la construcción de edificios en donde los especialistas pudieran desplegar su dominio experto. A su vez, no se trataba solamente de una cruzada de los médicos contra las parteras, también se daba una disputa de poder entre los nuevos profesionales y los médicos generalistas. En esta sección cobra especial relevancia la división temporal en dos sub períodos. Desde 1900 a 1930, es cuando se consolidan la obstetricia y la pediatría como especialidades médicas y avanza así la medicalización del embarazo, el parto y la crianza. En el lapso que va de 1930 a 1946, la concentración se da sobre la construcción del "biotipo" de la mujer fértil que orienta el discurso eugenésico y ajusta representaciones orientadas a la fuerza física, abnegación, sacrificio y multiparidad.

En la segunda parte, "El registro textual", Eraso analiza las representaciones de la maternidad en la prensa cordobesa de corte liberal, $L a$ Voz del Interior, y en la católica, Los Principios, y toma también seis novelas de ficción. Para la autora, el culto mariano fue una respuesta estratégica a esta creciente presencia feminista en la escena porteña; era ya más importante celebrar la maternidad de María, más que su virginidad. Nuevamente, al tomar el caso de Córdoba, las diferencias con lo que sucedía en la capital se ponen en evidencia, como cuando se contrasta la falta de un movimiento feminista cordobés, situación que no impidió el aliento de la prensa liberal de la provincia a la participación política femenina. Los textos de ficción seleccionados también responden al canon porteño con características 
propias. Algunos enfatizan los aspectos corporales de la maternidad y denuncian el peligro de la degeneración racial; otros, en cambio, priorizan la dimensión espiritual, emocional y postulan a la maternidad como un atributo más o menos definitorio del ser mujer.

La tercera y última parte se ocupa del "El registro visual". La autora toma como fuentes de análisis materiales del fotoperiodismo y del campo artístico, y los considera espacios de consolidación y también de contestación de los discursos prevalecientes acerca de la maternidad. Es en esta última sección en donde aparece la subjetividad de la madre de una forma más clara. Por ejemplo, cuando analiza las representaciones del surrealismo, que estuvo articulado como movimiento artístico con el psicoanálisis, encuentra imágenes que van más allá de lo que el discurso médico o religioso permitía a las madres. Más que resaltar la carencia de imágenes producidas por artistas mujeres en este tema, propone analizar las producidas por los varones y de ese modo abrir las posibilidades de análisis sobre la producción circulante, señalando también cómo van transformándose las representaciones a lo largo de esa primera mitad del siglo XX y el peso que gana la cuestión política y la denuncia social de las condiciones materiales de la maternidad en algunos artistas.

Mientras nuevos mandatos se tejen en torno a las maternidades: discursos ecologistas que estigmatizan los pañales descartables; movimientos pro lactancia que asumen una cruzada moral contra los biberones; relecturas psicológicas que entienden beneficioso el apego y promueven licencias laborales prolongadas y una presencia maternal sin límites, resulta interesante la lectura de este libro que nos cuenta cómo han ido tramándose las representaciones de la maternidad, las exigencias que se hacen al rol y las resistencias que van emergiendo. Un libro necesario para la historiografía argentina y un aporte valioso para el debate contemporáneo sobre las diversas formas de ser madre y las políticas necesarias para ejercer ese rol en un marco de derechos y reconocimiento social (Felitti, 2011).

\section{REFERENCIAS}

FELITTI, Karina.

Madre no hay una sola: experiencias de maternidad en la Argentina. Buenos Aires: CICCUS. 2011.
NARI, Marcela.

Políticas de maternidad y maternalismo político: Buenos Aires (1890-1940). Buenos Aires: Biblos. 2004. 